\title{
Acta Cirúrgica Brasileira indexed in ISI WEB OF SCIENCE (Thomson Reuters)
}

Acta Cirúrgica Brasileira indexada no ISI (Thomson Reuters)

Saul Goldenberg *

Founder, Editor-in-Chief

Finally we reach the top of indexation.

Acta Cirúrgica Brasileira was indexed step by step:

1. 1987. INDEX MEDICUS LATINO AMERICANO - LILACS

2. 1997. Scientific Electronic Library Online - SciELO - www.scielo.br/acb

3. 2005, MEDLINE/PUBMED and EMBASE

4. 2007. SCOPUS

5. 2007, Science Citation Index Expanded (SCIE).

Now, we look forward to increase the impact factor of the journal. 